\title{
Notes on Rubiaceae from India
}

\author{
Mohan Gangopadhyay ${ }^{\bowtie}$ \\ 33 D, Motilal Nehru Marg, Kolkata - 700029. \\ 凶Corresponding author: mgangopadhyay555@gmail.com

\section{भारत से रूबिऐसी कुल पर टिप्पणी} \\ मोहन गंगोपाध्याय
}

\section{सारांश}

भारत से रूबिएसी कुल की जातियों के दो नये नाम एवं दो नवीन संयोजनों को प्रस्तुत शोध पत्र में प्रस्तावित किया गया है।

\section{ABSTRACT}

Two new names and two new combinations are proposed for few taxa from family Rubiaceae.

Keywords: Rubiaceae, Nomenclature, new names, new combination, Morinda, Psychotria

\section{INTRODUCTION}

During the study of the family Rubiaceae in Indian context, few nomenclatural problems have been observed, which required some nomenclatural changes either by proposing new names or new combination which are appended below.

1. Ixora monticola (Hiern) Kuntze, (Revis. Gen. Pl. 1: 287. 1891) based on Pavetta monticola Hiern, (Fl. Trop. Afr. 3: 170. 1877) was a preoccupied name based on different type (Upper Guinea. Summit of the Peak of St. Thomas, Mann). Ixora monticola Gamble in Bull. Misc. Inform. Kew 1920: 246. 1920 was a latter homonym of it. So, this valid taxon requires a new name which is proposed as below.

Ixora deeprae M. Gangop. nom. nov. Ixora monticola Gamble in Bull. Misc. Inform. Kew 1920: 246. 1920 \& Fl. Madras 445. 1921, non (Hiern) Kuntze, 1891 (Lecto type: High wavy mountains near Cumbum,
300 - 1200 m, Madurai District, May 1917, Blatter \& Hallbergh 254 (CAL); para lectotypes: Blatter \& Hallbergh 25 \& 966 (CAL) selected by T. Husain \& S. R. Paul in J. Econ. Tax. Bot. Addl. Ser. 6: 98. 1989.

The species epithet is given in the loving memory of Late Deepra Chattopadhyay, the elder sister of the author.

2. Morinda reticulata Gamble (1920) is the later homonym of Morinda reticulata Benth. (1867) which was published based on a different type \{Australia, Albany Island; N.E. Coast, W. Hill; A. Cunningham (K)\} and is a synonym of Coelospermum decipiens Baill; thus invalid. A new name is proposed herewith as

Morinda pratimae M. Gangop., nom. nov. Morinda reticulata Gamble in Bull. Misc. Inform. Kew 1920: 248 1920, non Benth., 1867 \& Fl. Pres. Madras 652. 1921 (Types: South India: Travancore (Kerala), $600 \mathrm{~m}$ alt., April 1895, Bourdillon 591; at Kulathurpolay, June 
1913, M. Rama Raw 1281); C. N. Mohanan \& A. N. Henry, Fl. Thiruvananthapuram 237. 1994.

The species epithet is chosen in respect of Smt. Pratima Gangopadhyay, mother of the author .

3. Psychotria fulva Buch.-Ham. ex Hook. f. (1880) is a synonym of Psychotria monticola Kurz. The well-known south Indian variety Psychotria fulva Buch.-Ham. ex Hook. f. madraspatana (Hook. f.) Gamble (1920) is valid, so that require to transfer under Psychotria monticola. Hence a combination is proposed here.

Psychotria monticola Kurz var. madraspatana (Hook. f. ) M. Gangop. comb. nov.

Psychotria fulva Buch.-Ham. ex Hook. f. var. madraspatana (Hook. f.) Gamble, Madras 642. 1921; Deb \& M. Gangop. in J. Econ. Tax. Bot. Addl. Ser.7: 106.1989. P. madraspatana Hook. f., Fl. Brit. India 3: 167.1880 (Type: "Herb. Madras," Wallich. in Numer. List 8366 (CAL!). Uragoga madraspatana (Hook.f.) Kuntze, Revis. Gen. Pl. 2: 961. 1891.

4. Based on the taxonomic judgement the taxon Morinda aspera Wight \& Arn. (1834) is reduced to varietal rank under the species Morinda tinctoria Roxb. (1824) which was synonym of Morinda pubescens Sm. So a new varietal combination has proposed here as below.

\section{KEY TO THE VARIETIES}

1a. Plants tomentose

b. Plants uniformly scabrid var. pubescens var. aspera
Morinda pubescens Sm. var. aspera (Wight \& Arn.) M. Gangop., comb. nov. Morinda aspera Wight \& Arn., Prodr. Fl. Ind. Orient. 420. 1834 (Type: Wight cat. n. 1320). M. tinctoria Roxb. var. aspera (Wight \& Arn.) Hook. f., Fl. Brit. India 3: 156. 1880.

\section{ACKNOWLEDGEMENT}

The author is grateful to the Director, Botanical Survey of India, for encouragement and facilities.

\section{REFERENCES}

ANONYMOUS, 1920. XXXVIII.- DECADES KEWENSES. Plantaeum Novarum in Herbario Horti Regii Conservatarum. Bull. Misc. Inform. Kew 1920: 245 - 250.

BENTHAM, G. 1867. Flora Australiensis. Vol. 3: London.

GAMBLE, J. S. 1921. Flora of the presidency of Madras. Part 4. London.

HIERN, W. P. 1877. Rubiaceae in Oliver, Flora Tropical Africa. Vol. 3: 33 - 247. London.

HOOKER, J. D.1880 - 1881. Rubiaceae. The flora British India. Vol.3.17 - 210. London.

HUSAIN, T. AND S. R. PAUL, 1989. Taxonomic studies on Indian species of genus Ixora L. (Rubiaceae). J. Econ. Tax. Bot., Addl. Ser. 6: 1 - 205. Jodhpur.

KURZ, S. 1872. New Burmese Plants (Part First). J. Asiat. Soc. Bengal Pt. 2. Nat. Hist.41(2): 291 - 317.

WIGHT, R. 1834. Prodromus florae peninsla Indiae Orientalis. Vol. 1. London. 